\title{
Bioactivation of Carbonated Mineral Water with Passion Fruit Microcapsules
}

\author{
Morais A. B. L. ${ }^{1,}$, , Xavier A. C. R. ${ }^{1}$, Silva G. F. ${ }^{2}$, Silva M. A. A. P. ${ }^{1}$, Pagani A. A. C. ${ }^{1}$ \\ ${ }^{1}$ Department of Food Technology, Federal University of Sergipe, Sergipe, Brazil \\ ${ }^{2}$ Laboratory for Alternative Technologies - Federal University of Sergipe, Sergipe, Brazil
}

Email address:

alaizamorais@hotmail.com (Morais A. B. L.), alaizablmorais@gmail.com (Morais A. B. L.)

\section{To cite this article:}

Morais A. B. L., Xavier A. C. R., Silva G. F., Silva M. A. A. P., Pagani A. A. C.. Bioactivation of Carbonated Mineral Water with Passion Fruit Microcapsules. International Journal of Nutrition and Food Sciences. Vol. 4, No. 3, 2015, pp. 310-319.

doi: $10.11648 /$ j.ijnfs. 20150403.18

\begin{abstract}
The ionic gelation is a technique of microencapsulation by a reaction between a polymer solution and an ionic solution. This technique can protect the nutraceutical bioactive compounds. This study used the process of ionic gelation solution with sodium alginate in order to obtain a new product: a bioactive water from passion fruit microcapsules placed in the carbonated mineral water. The physical-chemical, microbiological stability, and migration of the bioactive compounds of microcapsule for water for 35 days at $5 \pm 1{ }^{\circ} \mathrm{C}$ was verified. For the microcapsules, it was possible to verify that the levels of ascorbic acid and carotenoids decreased during the storage period, and phenols remained constant $(\mathrm{p} \leq 0,05)$. Microcapsules and water presented balance of the ascorbic acid, carotenoids and phenols levels $(p \leq 0,05)$. This result indicates migration of the bioactive compounds of the microcapsule to water and consequently the bioactivation of carbonated mineral water.
\end{abstract}

Keywords: Ionic Gelation, Passion Fruit, Water, Migration, Bioactive Compounds

\section{Introduction}

The natural mineral water is characterized by a defined and constant content of certain mineral salts, trace elements and other constituents, considering the natural fluctuations (Brasil, 2005). Moreover, it is free from any calories, sugars or artificial ingredients (Mineral Waters of the World, 2013).

Water plays an essential role in the human body. It is used for digestion, absorption and transport of nutrients; besides maintaining the body temperature stabled; It is needed in the formation of all tissues, among other attributes (Oliveira \& Marchini, 1998; Castro et al., 2010). The loss of $3 \%$ of the total body water causes fatigue and $10 \%$ serious risk of death. Depending on the climate, diet, age, weight, level of physical activity, renal function, and other factors, the human being should drink about 1,5 to 3 liters of water per day (Mineral Waters of the World, 2013).

The sale of bottled water increases progressively. If the projections become real, the global consumption of the product is expected to register growth higher than $100 \%$ by 2021, compared to approximately $30 \%$ of carbonated beverages and beers. In this scenario, Brazil is the seventh largest producer of water on the planet and has a growth rate close to 20\% annual production (Água \& Vida, 2012).

The increase in water sales is due to population growth; reduction in the supply of drinking water by governments and; consumer behavior, who has been seeking for a healthy lifestyle and wellness (Moura et al., 2011). The search for quality of life extends to nutritional care, characterized by an increasing demand for healthy products with nutritional and sensory characteristics close to fresh foods (Endo et al., 2009).

Searches invest in water-based products incorporating flavors, vitamins and/or minerals; therefore known in the United States and Europe as "waters with added value" (Endo et al., 2009). Recently, industrialized beverages from many brands, called "low-calorie soft drinks" also appeared on the market (products with slightly aerated sugar zero), which constitutes an attractive to consumers in competition with carbonated mineral water.

The ionic gelling microencapsulation is a technique that occurs by a reaction between a polymeric solution, containing the nutrients, and an ionic solution in suitable concentrations (Mukai-Correa et al., 2005). 
Microencapsulation with alginate stands out because of the benefits of daily intake of alginates as fiber to reduce blood sugar and cholesterol, as well as its ability to prolong the life of the product. It may result in a final product that protect the bioactive nutraceutical compounds of encapsulated food from moisture and heat, and improve stability and bioavailability of these compounds, preserving foods during processing and storage (Pasin et al., 2012).

The passion fruit is a tropical fruit tree native from Brazil, whose cultivation has evolved very quickly (Rizzi et al., 1998). Currently the country is the world leader in production and consumption of fruit (IBGE, 2010). Passion fruit is a fruit known for its strong flavor besides being a source of nutritional constituents which presents several beneficial actions to humans, such as the antioxidant activity. Among these bioactive compounds, we highlight ascorbic acid, phenolics and carotenoids.

The bioactivation of products can be performed by adding foods rich in bioactive compounds in other foods in where they are not found. This process occurs through migration and/or interaction between components of food matrices, may occur faster or slower, which will depend on the composition of the foods studied.

Based on the properties of water and the growth of its consumption by the population, coupled Brazil's leadership in the production of passion fruit and the bioactive compounds for passion fruit, the study used the process of ionic gelation with sodium alginate solution for the production of passion fruit microcapsules, checking the stability of the microcapsules in carbonated mineral water and the bioactivation of this water through the migration of the bioactive compounds of passion fruit.

\section{Material and Methods}

The work was developed in the Laboratory of Food Analysis, Department of Food Technology of the Federal University of Sergipe, in São Cristóvão, Sergipe, Brazil.

The passion fruit (Passiflora edulis Sims f. Flavicarpa.) pulp was provided by agro fruit pulp Nova Descoberta Boquim, Sergipe, Brazil. The material was conducted in coolers to the Laboratory of Food Analysis and stored at $18^{\circ} \mathrm{C}$.

A carbonated natural mineral water (of a particular trademark) was obtained in the local market of the city of Aracaju, Sergipe, Brazil. We used carbonated water due to the bactericidal effect of carbon dioxide used for reducing the $\mathrm{pH}$ of the water.

\subsection{Obtaining the Juice}

The passion fruit pulp was filtered through a sieve and the juice was obtained by addition of water $(70 \%$ pulp and $30 \%$ water) followed by homogenization in a blender.

\subsection{Ionic Gelation}

For the process of ionic gelation, the dripping methodology was used with Caviar Box ${ }^{\circledR}$ kit in which two solutions were used: Solution (1): A solution composed of passion fruit juice, sodium citrate ( $\mathrm{pH}$ adjustment juice to 4,00 ) and sodium alginate (at a ratio of $1,8 \%$, since higher percentages gelled the juice before immersion in calcium chloride). Solution (2): $1 \%$ aqueous solution of calcium chloride.

The solution (1) was sucked into the Caviar Box® kit and dropped into the solution (2). With a pierced instrument, the formed beads were drained and immersed in a water container for removing any residue from the second solution.

After washing, the microcapsules were packed in sterilized glass bottles of $300 \mathrm{~mL}$ (with the proportion of $90 \%$ of carbonated water and $10 \%$ microcapsules in each bottle). The product was sealed and pasteurized at $60{ }^{\circ} \mathrm{C}$ for 30 minutes and stored at $5 \pm 1{ }^{\circ} \mathrm{C}$ in exhibitors for 35 days.

\subsection{Physical Analysis}

\subsubsection{Yield}

The yield was obtained by weighing the passion fruit juice and then the weighing, next the microcapsules were obtained by calculating the ratio of the difference multiplied by 100 .

\subsubsection{Quantity of Active Ingredient Encapsulated (QPA)}

The reference is to the amount of active ingredient encapsulated (passion fruit pulp) in microcapsules and is calculated with the following equation.

QPA\% = Amount of active ingredient encapsulated / weight of microcapsules*100

\subsubsection{Mass Loss of the Active Ingredient Encapsulated}

The drained weight of the microcapsules in water stored in the period of 35 days to see if there was a loss of mass of the active ingredient encapsulated into the water was observed.

\subsection{Analysis Physicochemical}

Physico-chemical analysis to characterize the pulp, juice and passion fruit microcapsules were made as well as the final product (bioactive water) for 35 days at $5 \pm 1{ }^{\circ} \mathrm{C}$. For bioactive water, analyzes were performed separately in the microcapsules and in the carbonated mineral water, due to the study of compounds migration between the two components of the product. The samples were subjected to the following tests:

\subsubsection{Moisture}

By direct oven drying at $105{ }^{\circ} \mathrm{C}$ to constant weight, following the method 012 in Chapter IV of the Adolfo Lutz Institute (2005).

\subsubsection{Ashes or Mineral}

Method for the incineration in a muffle furnace by AOAC method 900.02 (1996).

\subsection{3. $\mathrm{pH}$}

The Potentiometric method following the methodology of Adolfo Lutz Institute (2005, 017 / IV) was used. 


\subsubsection{Acidity}

Determined by the method of titratable acidity according to the AOAC method $\mathrm{n}^{\circ} 22.058$ (1984) and expressed in $\mathrm{g}$ of citric acid / $100 \mathrm{~g}$.

\subsubsection{Soluble Solids ( ${ }^{\circ}$ Brix $)$}

A bench Abbé refractometer was used and the result was expressed in ${ }^{\circ}$ Brix.

\subsubsection{Ascorbic Acid}

In accordance to the method $\mathrm{n}^{0} 43.065$ of AOAC (1984), modified by Benassi \& Antunes (1988), in which it replaces the extraction solution of metaphosphoric acid by oxalic acid.

\subsubsection{Total Carotenoids}

The carotenoid levels were assessed following the method proposed by Lichtenthaler (1987) expressed in $\mu \mathrm{g} / \mathrm{g}$.

\subsubsection{Total Phenols}

The phenol levels were assessed following Ragazzi \& Veronesi (1973) with adaptations. $0,5 \mathrm{~mL}$ of filtered sample added $2 \mathrm{~mL}$ of Folin $0,02 \mathrm{~N}$ and $2 \mathrm{~mL}$ of aqueous $\mathrm{Na}_{2} \mathrm{CO}_{3}$ solution $(10 \%)$ were used. The tubes were homogenised by vortexing and kept at rest for 30 minutes in the dark. The reading was performed in a spectrophotometer at a wavelength of $765 \mathrm{~nm}$. A standard curve was constructed with gallic acid and phenol levels were expressed as $\mathrm{mg}$ gallic acid / 100g.

\subsubsection{Color}

Color readings were taken using the Minolta colorimeter Color Meter 200b.

\subsection{Microbiological Analysis}

Microbiological analysis of the fruit pulp and water were made. Analyses of passion fruit pulp were carried out before the production of the microcapsules in order to characterize the health of the pulp. Microbiological analysis of bioactive water aimed to verify the sanity of the product and the evaluation of shelf life was held every 7 days until the identification of microbiological deterioration of the product, defining the validity of the product.

The technique of the Most Probable Number (MPN) was used for quantifying total coliforms, fecal coliforms, Pseudomonas aeruginosa, Enterococcus and Clostridium sulphite reducers to $46^{\circ} \mathrm{C}$.

The yeast and mold count was performed on the surface with the culture medium potato dextrose agar (PDA) and acidified with tartaric acid solidified, the plates were incubated at $25{ }^{\circ} \mathrm{C}$ for 5 days to count the colonies embodiment.

\subsection{Statistical Analysis}

In order to accurate interpretation, the experimental data of the samples were obtained in triplicate and evaluated by Assistant computer program, version 7.7 beta, by analysis of variance (ANOVA). The Tukey test was applied at 5\% probability $(\mathrm{p} \leq 0,05)$, so that, not only differences in means between the pulp, juice and freshly processed microcapsules could be detected, but also differences in means of the components of bioactive water (microcapsules and mineral water) during storage.

\section{Results and Discussion}

\subsection{Physical Analysis}

\subsubsection{Yield}

The yield microcapsules passion was $62,12 \%$, due to product losses in Caviar Box ${ }^{\circledR}$. It retained the passion fruit juice and, especially, the deformation of some microcapsules, which had to be discarded because of their differences from the established standard, that it was in spherical form.

Ramos (2006) microencapsulated the volatile fraction of oleoressina copaiba in arabic gum by spray drying with an average yield of $64,4 \%$, which is considered good for a pilot process. Xavier (2014) noted the yield $70 \%$ pearled passion fruit in their studies with passion fruit pearls obtained by ionic gelation.

\subsubsection{Quantity of Active Ingredient Encapsulated (QPA)}

The QPA was $65,8 \%$, since the passion fruit pulp was diluted with $30 \%$ water and added $2,4 \%$ sodium citrate and $1,8 \%$ sodium alginate. If this study did not consider dilution of the pulp - with the purpose to decrease the acidity and soften the strong taste of passion fruit - the QPA would be $95,8 \%$.

\subsubsection{Mass Loss of the Active Ingredient Encapsulated}

According to Table 1 it was observed that the mass of the microcapsules remained constant during storage in water. Ramos (2006) microencapsulated oleoressina copaiba with Arabic gum by spray drying. Temperatures of $25{ }^{\circ} \mathrm{C}$ and $40{ }^{\circ} \mathrm{C}$ with relative humidity of $50 \%$ for 60 days showed that the microencapsulation of the volatile fraction minimized, although it did not prevent oxidation and loss of mass.

Table 1. Weight of the microcapsules stored in water for 35 days.

\begin{tabular}{ll}
\hline Storage time (days) & Microcapsules weight ${ }^{1,2}(\mathbf{g})$ \\
\hline 0 & $26,00^{\mathrm{a}}$ \\
7 & $25,61^{\mathrm{a}}$ \\
14 & $26,18^{\mathrm{a}}$ \\
21 & $25,55^{\mathrm{a}}$ \\
28 & $25,07^{\mathrm{a}}$ \\
35 & $26,94^{\mathrm{a}}$ \\
\hline
\end{tabular}

${ }^{1}$ Averages; ${ }^{2}$ Averages followed by the same letter do not differ statistically by Tukey test at $5 \%$ probability.

Vicentino et al. (2011) observed that grapes coated with cassava starch acetylated at $5{ }^{\circ} \mathrm{C}$ and $70 \% \mathrm{RH}$ lost smaller amount of mass $(7,46 \%)$ when compared to control grape $(14,1 \%)$ in 25 days. Cooling slowed the weight loss product, which also occurred in the present work, together with the ability of alginate water retention (Mukai-Correa et al., 2005). 


\subsection{Analysis Physicochemical}

\subsubsection{Characterization of the Pulp, the Juice and the Microcapsules}

Table 2 shows the results of the physicochemical analysis of the pulp, juice and passion fruit microcapsules for comparison of the changes that occurred after processing. The pulp presented a significant difference at $5 \%$ (Table 2 ) in most analyzes due to the addition of water and sodium citrate for obtaining the passion fruit juice with $\mathrm{pH}$ suitable for gelation.

Table 2. Characterization of the pulp, the juice and the microcapsules.

\begin{tabular}{llll}
\hline Chemical composition & Pasteurized frozen pulp & Passion fruit juice & Microcapsule pasteurized \\
\hline Moisture $(\%)$ & $91,50^{\mathrm{b}}$ & $94,77^{\mathrm{a}}$ & $92,98^{\mathrm{a}}$ \\
Ash $(\%)$ & $0,66^{\mathrm{b}}$ & $1,31^{\mathrm{a}}$ & $1,34^{\mathrm{a}}$ \\
$\mathrm{pH}$ & $3,07^{\mathrm{b}}$ & $4,00^{\mathrm{a}}$ & $3,61^{\mathrm{a}}$ \\
Total soluble solids $\left({ }^{\circ}\right.$ Brix) & $11,40^{\mathrm{a}}$ & $6,17^{\mathrm{b}}$ \\
Acidity $(\mathrm{g}$ citric acid / 100g) & $2,23^{\mathrm{a}}$ & $0,91^{\mathrm{b}}$ & $0,89^{\mathrm{b}}$ \\
Ascorbic acid $(\mathrm{mg} / \mathrm{g})$ & $10,20^{\mathrm{a}}$ & $8,88^{\mathrm{a}}$ & $7,53^{\mathrm{a}}$ \\
Total carotenoids $(\mu \mathrm{g} / \mathrm{g})$ & $20,46^{\mathrm{a}}$ & $19,99^{\mathrm{a}}$ & $19,91^{\mathrm{a}}$ \\
Total phenols $(\mu \mathrm{g}$ gallic acid / g) & $598,37^{\mathrm{a}}$ & $418,86^{\mathrm{a}}$ & $170,26^{\mathrm{b}}$ \\
Color $(\mathrm{L})$ & $18,40^{\mathrm{b}}$ & $35,57^{\mathrm{a}}$ & $34,03^{\mathrm{a}}$ \\
Color $\left(\mathrm{a}^{*}\right)$ & $+2,37^{\mathrm{b}}$ & $+4,20^{\mathrm{a}}$ & $+3,23^{\mathrm{a}}$ \\
Color $\left(\mathrm{b}^{*}\right)$ & $+12,30^{\mathrm{b}}$ & $+28,76^{\mathrm{a}}$ & $82,43^{\mathrm{a}}$ \\
Color $\left(H u e^{\mathrm{o}}\right)$ & $79,10^{\mathrm{a}}$ & $84,62^{\mathrm{a}}$ & $83,47^{\mathrm{a}}$ \\
\hline
\end{tabular}

${ }^{1}$ Averages; ${ }^{2}$ Averages followed by the same letter in the line do not differ statistically by Tukey test at $5 \%$ probability.

The moisture content of the pulp was $91,50 \%$ (Table 2), which is in agreement with the values reported by other authors, such as: Oliveira et al. (2011) and Xavier (2014), that when studying the pulp of passion fruit found content of $84,87 \%$ and $90,57 \%$ respectively. When comparing the pulp to the juice and the microcapsules, it is found that the latter had higher moisture compared to the pulp, with a significant difference. This increase in moisture content is justified because of the addition of water to obtain the juice, and a small decrease in the moisture content of the juice for the microcapsules occurred because of the addition of alginate.

In relation to the ash content (Table 2), the value for the pulp was 0,66 which was higher than the one found by Xavier (2014) who, during analyzes of the passion fruit pulp content found 0,47 . The ash content of the pulp was lower than the ash content of the juice and the microcapsules, certainly the alginated film formed during the ion gelation, as well as the sodium citrate and calcium chloride, incorporated ash content to the final product.

The $\mathrm{pH}$ of the pulp $(3,07)$ (Table 2$)$ had the lowest amount of juice $(4,00)$, and the microcapsules $(3,61)$, due to the effect adjustment of the $\mathrm{pH}$ juice with sodium citrate for obtaining the passion fruit juice with suitable $\mathrm{pH}$ for gelation. Since extremes variations of $\mathrm{pH}$ degrade the alginate polymer, consequently there is loss of gel properties (Paul et al, 2009; Pasin et al, 2012).

In this study, the value found for the pulp brix (Table 2) was 11,4 , which is appropriate for patterns established in Brazil. The pulp showed ${ }^{\circ}$ Brix value (Table 2) higher than juice and the microcapsule. The reduction of soluble solids is justified by correcting the $\mathrm{pH}$, which was performed with the use of water and sodium citrate, and also leaching of soluble solids that may have occurred during immersion in a solution of calcium chloride and then in water to remove the excess from the calcium microcapsule.

For acidity, pulp showed 2,23 g of citric acid / $100 \mathrm{~g}$
(Table 2), above the value found by Xavier (2014), which was $0,75 \mathrm{~g}$ of citric acid / $100 \mathrm{~g}$. The sodium citrate is a food additive used in the juice industry with acidity regulator including the addition of water favors a significant reduction $(5 \%)$ in the acidityrate for the juice and the microcapsules (Table 2).

The passion fruit pulp averaged ascorbic acid 10,20 mg / $100 \mathrm{~g}$ (Table 2), which is higher than the one compared to TACO (2011), which has the value of 7,3 mg / 100g Vitamin $\mathrm{C}$ in the passion fruit frozen pulp.

The contents of carotenoids and ascorbic acid did not differ in the three samples (Table 2), indicating the ability of the alginate microcapsule for immobilizing water in the chain (preventing hydrolysis) and preventing oxidation of the respective compounds, even with the pasteurized microcapsules. The result was also observed by De'Nobili et al. (2013) who evaluated the alginate films with different composition of copolymers and glycerol for stability of the ascorbic acid.

The decrease, not significant, of the ascorbic acid content can be attributed due to the incorporation of air during processing, favoring aerobic degradation reactions, losses can also occur due to chemical oxidation and/or thermal degradation through pasteurization.

For total phenols (Table 2), it was observed that the pulp showed 598,37 mg gallic acid / 100g. Different value obtained by Couto et al. (2011) and Lessa (2011), who obtained 35 and 23,28 mg gallic acid / $100 \mathrm{~g}$ from passion fruit pulp acid to organic and conventional fruit and 190,25 to $210,85 \mathrm{mg}$ gallic acid / $100 \mathrm{~g}$, respectively. According to Kim et al. (2003), the discrepancy between the results of phenols found in the studies may be explained by variations in maturity, variety, practices, cultures, geographical origin, maturity stage and fruit harvest conditions.

In the processing there was a significant decrease in gallic acid when microencapsulation was conducted (Table 2). Rose 
et al. (2014) reported that encapsulation efficiency depends on the encapsulated compound and the phenolic polysaccharide used. Rose et al. (2014) found that for the encapsulation of phenolic compounds wild blackberry (Rubus fruticosus), the chitosan encapsulated only epicatechin and gallic acid, although it was more effective in encapsulating the gallic acid. Xanthan gum had a similar encapsulation for epicatechin and gallic acid. The combination of xanthan and quisotana obtained $r$ capacity for encapsulating catechin greater than the gallic acid.

The results of color parameters $(\mathrm{L}=18,4, \mathrm{a} *=+2,37 \mathrm{~b} *$ $\left.=+12,3 ; \mathrm{Hue}^{\mathrm{o}}=79,1\right)$ showed the orange color of the pulp (Table 2). When comparing the color parameters of the pulp to the juice color parameters, it is observed that they show a significant different. However, the microcapsules did not differ significantly from the juice in all parameters. It is also noted that the dilution of feedstock input contributes more to the color change than to the gelling with alginate.

Regarding the juice and the microcapsules, a small reduction in the parameters $\mathrm{L}, \mathrm{a}^{*}$ and $\mathrm{b}^{*}$ has been observed, which was also observed by Passos et al. (2009), when they applied alginate based coatings in mangoes, Silva et al. (2010), in the encapsulation of anthocyanins with maltodextrin, focusing the loss of coloration originated.

\subsubsection{Characterization of Bioactive Water During Storage}

The results of physicochemical analyzes of bioactive water stored in glass packaging are presented below.

Table 3. Characterization of components of bioactive water at $5 \pm 1{ }^{\circ} \mathrm{C}$ packaged in glass.

\begin{tabular}{|c|c|c|c|}
\hline Chemical composition & Storage time (days) & Passion fruit microcapsule & Carbonated mineral water \\
\hline \multirow{6}{*}{ Moisture $(\%)^{1,2}$} & 0 & $92,98^{\mathrm{bB}}$ & $99,99^{\mathrm{aA}}$ \\
\hline & 7 & $97,46^{\mathrm{aB}}$ & $99,40^{\mathrm{aA}}$ \\
\hline & 14 & $97,28^{\mathrm{aB}}$ & $99,50^{\mathrm{aA}}$ \\
\hline & 21 & $97,28^{\mathrm{aB}}$ & $99,43^{\mathrm{aA}}$ \\
\hline & 28 & $96,97^{\mathrm{aB}}$ & $99,48^{\mathrm{aA}}$ \\
\hline & 35 & $97,34^{\mathrm{aB}}$ & $99,55^{\mathrm{aA}}$ \\
\hline \multirow{6}{*}{$\operatorname{Ash}(\%)^{1,2}$} & 0 & $1,34^{\mathrm{aA}}$ & $0,01^{\mathrm{aB}}$ \\
\hline & 7 & $0,42^{\mathrm{bA}}$ & $0,17^{\mathrm{aB}}$ \\
\hline & 14 & $0,52^{\mathrm{bA}}$ & $0,12^{\mathrm{aB}}$ \\
\hline & 21 & $0,47^{\mathrm{bA}}$ & $0,08^{\mathrm{aB}}$ \\
\hline & 28 & $0,38^{\mathrm{bA}}$ & $0,06^{\mathrm{aB}}$ \\
\hline & 35 & $0,35^{\mathrm{bA}}$ & $0,05^{\mathrm{aB}}$ \\
\hline \multirow{6}{*}{$\mathrm{pH}^{1,2}$} & 0 & $3,61^{\mathrm{bB}}$ & $6,07^{\mathrm{aA}}$ \\
\hline & 7 & $3,69^{\mathrm{bA}}$ & $3,63^{\mathrm{cA}}$ \\
\hline & 14 & $3,67^{\mathrm{bA}}$ & $3,60^{\mathrm{cA}}$ \\
\hline & 21 & $4,53^{\mathrm{aA}}$ & $4,27^{\mathrm{bA}}$ \\
\hline & 28 & $3,43^{\mathrm{bA}}$ & $3,60^{\mathrm{cA}}$ \\
\hline & 35 & $3,60^{\mathrm{bA}}$ & $3,57^{\mathrm{cA}}$ \\
\hline \multirow{6}{*}{ Acidity ( $\mathrm{g}$ citric acid / 100g) $)^{1,2}$} & 0 & $0,89^{\mathrm{aA}}$ & $0,00^{\mathrm{bB}}$ \\
\hline & 7 & $0,10^{\mathrm{cA}}$ & $0,11^{\mathrm{aA}}$ \\
\hline & 14 & $0,19^{\mathrm{bA}}$ & $0,12^{\mathrm{aB}}$ \\
\hline & 21 & $0,08^{\mathrm{cA}}$ & $0,10^{\mathrm{aA}}$ \\
\hline & 28 & $0,09^{\mathrm{cA}}$ & $0,10^{\mathrm{aA}}$ \\
\hline & 35 & $0,11^{\mathrm{cA}}$ & $0,12^{\mathrm{aA}}$ \\
\hline \multirow{6}{*}{ Total soluble solids ( ${ }^{\circ}$ Brix $)^{1,2}$} & 0 & $6,17^{\mathrm{a}}$ & $\mathrm{Ta}$ \\
\hline & 7 & $\mathrm{Ta}$ & $0,70^{\mathrm{a}}$ \\
\hline & 14 & $\mathrm{Ta}$ & $0,50^{\mathrm{bc}}$ \\
\hline & 21 & $\mathrm{Ta}$ & $0,53^{\mathrm{ab}}$ \\
\hline & 28 & $\mathrm{Ta}$ & $0,33^{\mathrm{c}}$ \\
\hline & 35 & $\mathrm{Ta}$ & $0,53^{\mathrm{ab}}$ \\
\hline \multirow{6}{*}{ Ascorbic acid $(\mathrm{mg} / \mathrm{g})^{1,2}$} & 0 & $7,53^{\mathrm{aA}}$ & $0,00^{\mathrm{cB}}$ \\
\hline & 7 & $7,81^{\mathrm{aA}}$ & $7,43^{\mathrm{aA}}$ \\
\hline & 14 & $5,76^{\mathrm{abA}}$ & $5,82^{\mathrm{abA}}$ \\
\hline & 21 & $6,30^{\mathrm{abA}}$ & $6,30^{\mathrm{abA}}$ \\
\hline & 28 & $5,44^{\mathrm{abA}}$ & $5,57^{\mathrm{abA}}$ \\
\hline & 35 & $3,52^{\mathrm{bA}}$ & $3,54^{\mathrm{bA}}$ \\
\hline \multirow{6}{*}{ Total carotenoids $(\mu \mathrm{g} / \mathrm{g})^{1,2}$} & 0 & $19,91^{\mathrm{aA}}$ & $0,00^{\mathrm{bB}}$ \\
\hline & 7 & $6,57^{\mathrm{bA}}$ & $11,57^{\mathrm{aA}}$ \\
\hline & 14 & $7,34^{\mathrm{bA}}$ & $7,21^{\mathrm{aA}}$ \\
\hline & 21 & $7,56^{\mathrm{bA}}$ & $6,92^{\mathrm{aA}}$ \\
\hline & 28 & $5,70^{\mathrm{bA}}$ & $7,25^{\mathrm{aA}}$ \\
\hline & 35 & $6,51^{\mathrm{bA}}$ & $6,44^{\mathrm{aA}}$ \\
\hline \multirow{6}{*}{ Total phenols $(\mu \mathrm{g} \text { gallic acid } / \mathrm{g})^{1,2}$} & 0 & $170,26^{\mathrm{aA}}$ & $0,00^{\mathrm{cB}}$ \\
\hline & 7 & $177,45^{\mathrm{aA}}$ & $185,29^{\mathrm{abA}}$ \\
\hline & 14 & $205,56^{\mathrm{aA}}$ & $231,70^{\mathrm{aA}}$ \\
\hline & 21 & $161,11^{\mathrm{aA}}$ & $175,49^{\mathrm{bA}}$ \\
\hline & 28 & $190,52^{\mathrm{aA}}$ & $167,65^{\mathrm{aB}}$ \\
\hline & 35 & $172,22^{\mathrm{aA}}$ & $172,88^{\mathrm{bA}}$ \\
\hline
\end{tabular}




\begin{tabular}{llll}
\hline Chemical composition & Storage time (days) & Passion fruit microcapsule & Carbonated mineral water \\
\hline & 0 & $34,03^{\mathrm{a}}$ & - \\
& 7 & $21,37^{\mathrm{b}}$ & - \\
Color $(\mathrm{L})^{1,2}$ & 14 & $25,83^{\mathrm{ab}}$ & - \\
& 21 & $20,67^{\mathrm{b}}$ & - \\
& 28 & $22,00^{\mathrm{b}}$ & - \\
& 35 & $22,47^{\mathrm{b}}$ & - \\
& 0 & $+3,23^{\mathrm{ab}}$ & - \\
& 7 & $+3,07^{\mathrm{ab}}$ & - \\
Color $\left(\mathrm{a}^{*}\right)^{1,2}$ & 14 & $+3,23^{\mathrm{ab}}$ & - \\
& 21 & $+4,40^{\mathrm{a}}$ & - \\
& 28 & $+2,73^{\mathrm{b}}$ & - \\
& 35 & $+2,80^{\mathrm{b}}$ & - \\
& 0 & $+28,43^{\mathrm{a}}$ & - \\
Color $\left(\mathrm{b}^{*}\right)^{1,2}$ & 7 & $+25,20^{\mathrm{ab}}$ & - \\
& 14 & $+20,47^{\mathrm{ab}}$ & - \\
& 21 & $+19,03^{\mathrm{b}}$ & - \\
& 28 & $+23,07^{\mathrm{ab}}$ & - \\
& 35 & $+21,63^{\mathrm{ab}}$ & - \\
& 0 & $83,47^{\mathrm{a}}$ & - \\
& 7 & $82,93^{\mathrm{a}}$ & - \\
& 14 & $81,90^{\mathrm{a}}$ & - \\
& 21 & $75,60^{\mathrm{a}}$ & - \\
& 28 & $83,17^{\mathrm{a}}$ & - \\
\hline
\end{tabular}

${ }^{1}$ Averages; ${ }^{2}$ Averages followed by the same letter, lowercase in columns and uppercase in lines, not differ statistically by Tukey test at $5 \%$ probability. Ta: Trace amount

Table 3 presents the results of moisture in the microcapsule and water separately. The moisture of mineral water remained in constant storage differing significantly from microcapsules in the same storage time.

The moisture content of the microcapsules increased after seven days of storage in water, and remained constant until the 35th day of analysis (Table 3). This result was expected because of the alginate has a high capacity for water retention (Mukai-Correa et al. 2005). Another factor that may have caused the increase of moisture in the microcapsules was the decrease from the ashes in microcapsules and a portion of the ash content of the microcapsule migrated to water, as observed in Table 3 .

There was a significant reduction (5\%) $74,12 \%$ of ash content in the microcapsules at the end of storage (Table 3 ). Ash content showed up constant for the two products analyzed from the 7 th day of storage.

Oliveira (2011) observed an increase in of papaya ash drops obtained with sodium alginate stored in glass packaging $(1,56 \%$ increase) and packaged polypropylene $(10,14 \%)$ after 21 days. Xavier (2014) observed no significant difference in the $5 \%$ ash content for pearls of passion fruit obtained by ionic gelation at 35 days of storage.

The difference in result of ash (minerals) obtained from previous work cited in this study can be justified due to the packaging of carbonated water in the microcapsules, in which there has been a migration of a portion of ash (minerals) from microcapsule to water.

No significant variations were observed in the $\mathrm{pH}$ in the microcapsules storage (Table 3). Except in the time of 21 days, both the microcapsules as water differ from other days of storage.

For water, it was noted that after 7 days of storage, there was a significant decrease in $\mathrm{pH}$ and in equilibrium with the $\mathrm{pH}$ of the microcapsules analyzed in periods of storage (Table 3). The constancy of $\mathrm{pH}$ is justified due to the buffering effect of the cell fluid and because of cell passion fruit organic acids (particularly citric acid) with sodium citrate (added to adjust the $\mathrm{pH}$ of the juice) which does not allow wide variations in $\mathrm{pH}$.

According to Almeida et al. (2006) in general, reduction of the acidity is associated to the increasing $\mathrm{pH}$, as it was also observed by Xavier (2014), in obtaining the passion fruit beads stored by ionic gelation $\pm 5{ }^{\circ} \mathrm{C}$. However; in this study, it was observed a decrease of $87,53 \%$ of the acidity of the microcapsule during the days of storage at constant $\mathrm{pH}$ (Table 3). There was a balance between the acidity of the components. For the carbonated water, acidity was constant between days storage.

For the content of Total Soluble Solids (TSS) (Table 3) there was a significant difference in microcapsule in the first analysis (time 0) and in storage, being checked trace amount of TSS. The water had TSS in storage.

Jiang (2013) studied mushrooms (Agaricus bisporus) immersed for 2 minutes in different concentrations of alginate $(1 \%, 2 \%$ and $3 \%)$ then placed in vials and aerated continuously with $100 \% \mathrm{O}_{2}$ for 16 days, $4{ }^{\circ} \mathrm{C}$. The results indicated that treatment with alginate coating $(2 \%)$ delayed changes in the concentration of soluble solids.

In the present work, the microcapsules made with alginate $(1,8 \%)$ were stored in water with carbon dioxide, which initially degraded a high TSS. It is also observed that the water leached a small part of the TSS (Table 3). Lozano (2010) reports that encapsulated packaged in water or in different means to the inside of the encapsulated, the diffusion of the soluble solids occur exponentially. 
The TSS leached into the water had a variation in behavior, however; the value obtained on the 7 th day of storage did not differ significantly from the value obtained on day 35 (Table $3)$.

Lozano (2010) selected three foods marketed in order to study the ionic gelation with filling in liquid. Grapecranberry juice, being its liquid filling the juice itself; peach pulp in syrup ( $\mathrm{pH}=3,61$ and $16^{\circ} \mathrm{Brix}$ ) and; cuitlacoche pulp at brine to $3 \%$. The products were sterilized and stored for 6 months. For the foods, the $\mathrm{pH}$ varied slightly and the humidity increased with storage. The results of $\mathrm{pH}$ and soluble solids in the liquid filling indicated no degradation of its components in storage.

The study of bioactive substances such as ascorbic acid, carotenoids and phenolic compounds, stands out for its importance in human nutrition, especially due to its antioxidant properties being able to prevent chronic nontransmissive diseases (Johnston \& Bowling, 2002).

During the storage period a migration of ascorbic acid (AA) of passion fruit microcapsules for carbonated water was observed (Table 3 ). From the 7 th day there was the equating of the ascorbic acid content of the two product components (microcapsule and water) (Figure 1). There was no significant difference in the ascorbic acid content of the microcapsule and water storage (Table 3 ).

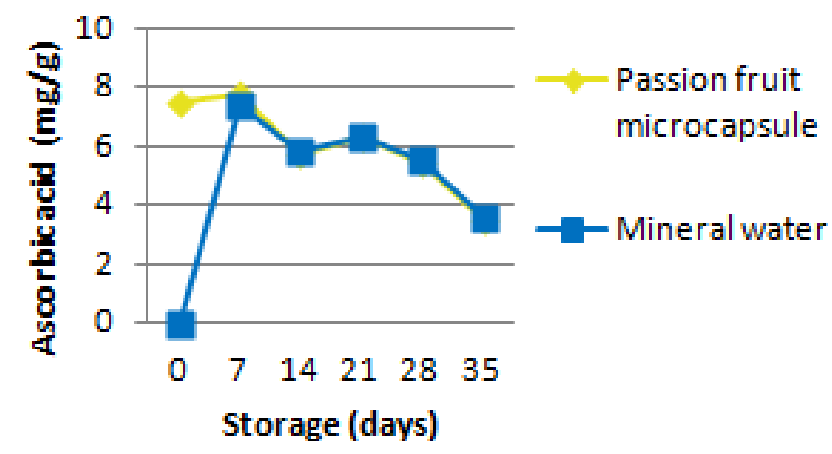

Figure 1. Ascorbic acid concentrations of bioactive water's components at $5 \pm 1{ }^{\circ} \mathrm{C}$ in glass bottles.

Despite the decrease with storage, a significant difference $(5 \%)$ in the levels of AA was observed only after 35 days of analysis for the two components of the product (microcapsule and water) (Table 3 ).

Jiang (2013) observed the degradation of ascorbic acid in mushrooms (Agaricus bisporus) immersed for 2 minutes in different alginate concentrations, stored at $4{ }^{\circ} \mathrm{C}$ for 16 days in aerated vials continuously with $100 \% \mathrm{O}_{2}$. The degradation of ascorbic acid ascorbic acid in mushroom controls and treated with alginate coating $(1 \%, 2 \%$ and $3 \%)$ was $72,63 \%, 70,58 \%$, $61,93 \%$ and $57,82 \%$, respectively.

The incorporation of alginate in coating formulations can reduce diffusion of $\mathrm{O}_{2}$, decreasing the ripening rate of fruits and consequently better preserving the contents of ascorbic acid and delaying senescence (Jiang, 2013). In this study there was a loss of ascorbic acid, about 53,35\% and 52,35\% for the microcapsules and carbonated water, stored together to $5 \pm 1{ }^{\circ} \mathrm{C}$ for 35 days (Table 3 ). However; the product continues with considerable content of ascorbic acid.

With respect to total carotenoid, it was observed that there was a significant reduction $(67,02 \%)$ of carotenoids from the microcapsules in the first week of storage (Table 3). However; this decrease was not due to degradation of carotenoids, but to the compounds majority migration of the microcapsule into water observed from day 7 of storage. Only $8,92 \%$ of the initial carotenoids were degraded in the first week.

From the 14th day of storage, the two components of the product showed similar values of total carotenoids that remained until the last day of storage (Figure 2).

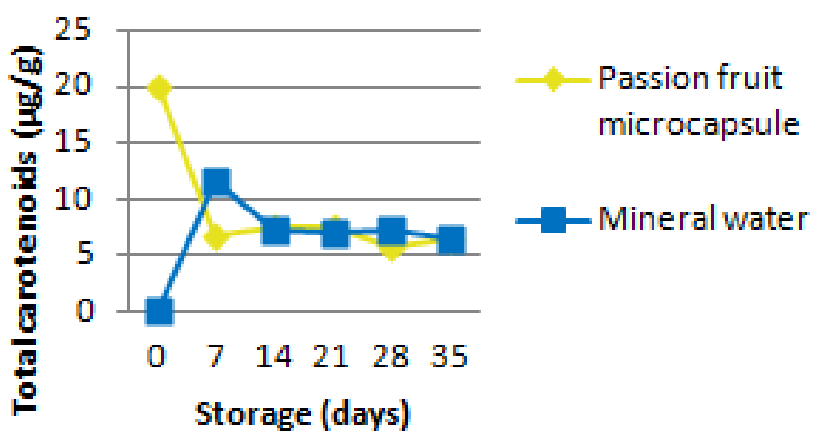

Figure 2. Total carotenoids concentrations of bioactive water's components at $5 \pm 1{ }^{\circ} \mathrm{C}$ in glass bottles.

After 35 days of storage, the reduction of carotenoids was $39,97 \%$ as compared to the content of the compounds of the microcapsules at time 0 (Table 3). In studies by Xavier (2014), there is a loss of $78,79 \%$ of total carotenoids in pearls passion fruit pulp encapsulated with $1,75 \%$ alginate and stored in glass containers at $5{ }^{\circ} \mathrm{C}$ for 35 days.

Guadarrama-Lezama et al. (2012) obtained and characterized non-aqueous extracts of red pepper (Capsicum annuиm L.), using three different oils (corn, safflower and sunflower) and their microencapsulated. The biopolymers were Arabic gum and maltodextrin. The reduction of carotenoids in the microcapsules was between $16 \%$ and $14 \%$.

Qv et al. (2011) used the complex coacervation method to increase the stability of lutein with $1 \%$ gelatin and Arabic gum $(1: 1)$ and $\mathrm{pH} 4,2$. The lutein reduction rate was $7,14 \%$ at $4{ }^{\circ} \mathrm{C} ; 9,84 \%$ at $25{ }^{\circ} \mathrm{C}$ after 30 days of storage.

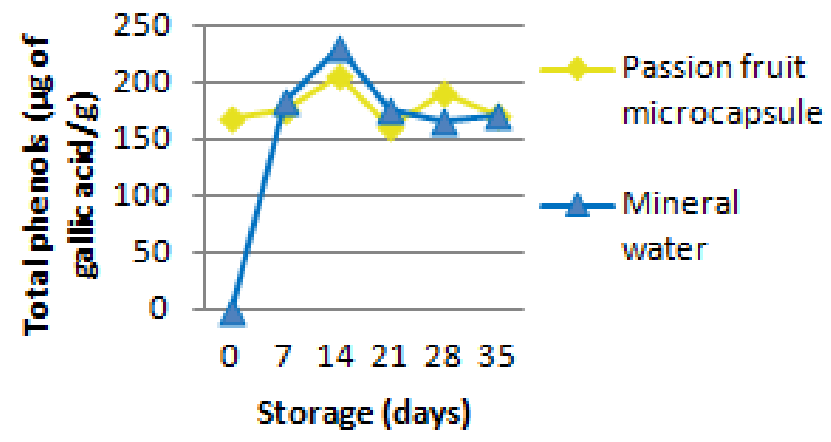

Figure 3. Total phenols concentrations of bioactive water's components at $5 \pm 1{ }^{\circ} \mathrm{C}$ in glass bottles. 
According to analysis of variance, there was no significant difference $(p \leq 0,05)$ in total phenols in microcapsules in the bioactive water storage (Table 3 ). From the $7^{\text {th }}$ day on, there was an equilibrium of the content of phenolics in the two components of the product (water and microcapsule) (Figure 3). There was no significant difference of phenolic microcapsule and water in the same storage time, except on day 28 (Table 3 ).

Rutz (2013) microencapsulated, by freeze-drying process, the juice of purple cherry in matrices of various hydrocolloids. The stability of carotenoids and phenolic compounds of the microparticles were evaluated during storage in the presence and absence of light for a period of 28 days, and at $4{ }^{\circ} \mathrm{C}$ and $25{ }^{\circ} \mathrm{C}$ for a period of 84 days. All hydrocolloids showed degradation of carotenoids and phenolic compounds showed high percentages of preservation in storage. The same behavior was observed in the present study (Table 3).

Arrazola et al. (2014) found that the microencapsulation of anthocyanins eggplant (Solanum melongena L.) by spray drying with maltodextrin, which was effective for holding the bioactive compound in isotonic drinks and drinks with aloe vera stored at $4{ }^{\circ} \mathrm{C}$ for 40 days.

Lightness (L) is a parameter which can vary from zero (black) to 100 (white). In this present study, the microcapsules of passion fruit showed values of $\mathrm{L}$ between 34,0333 to 20,6667 (Table 3), significantly reducing the storage period, indicating darkening of the microcapsule.

The parameter $a^{*}$ varies from red $(+a)$ to green $(-a)$. A significant reduction in the water storage was observed (Table 3), which shows a decrease in the product orange color. The parameter $b^{*}$ refers to the color variation between yellow $(+b)$ and blue $(b)$. The parameter $b^{*}$ ranged in storage, showing no significant difference between time 0 and time 35 (Table 3).

The change of the parameters $\mathrm{L}$ and $\mathrm{a}^{*}$ may be related to the occurrence of enzymatic browning reaction, oxidation or light incidence, since there was deterioration of ascorbic acid and carotenoids during the storage period studied.

The Hue angle $\left(\mathrm{Hue}^{\mathrm{o}}\right)$ of color can vary from 0 to $360^{\circ}$, while the $0^{\circ}$ corresponds to red, $90^{\circ}$ corresponds to yellow, $180^{\circ}$ to green and $270^{\circ}$ to blue. The color parameter Hue ${ }^{\circ}$ oscillated in storage, but no presented significant difference (Table 3).

Lozano (2010) encapsulated an isotonic solution (0,3 M sucrose $-0,1 \mathrm{M} \mathrm{NaCl})$, with artificial lime dye $(0,1 \%)$ in alginate $(0,8 ; 1 ; 1,2 \%)$, using calcium chloride $1 \%$. The encapsulated were loaded in isotonic solution and in water, and stored under refrigeration for 15 days. The diffusion of color occurred exponentially encapsulated in bottled water.

This phenomenon must be taken into account during the storage of an encapsulated food, since the diffusion of the encapsulated inside, related to the liquid filling, may have consequences for the appearance and acceptance of the product (Lozano, 2010).

The addition of ascorbic acid and citric acid is one viable alternative for maintaining color, the content of bioactive compounds, and for increasing the antioxidant activity of the product, as reported by Sanchez-Robles et al. (2013). The authors studied the effect of alginate-based edible coating, as a vehicle of antibrowning agent (ascorbic and citric acid) in color, content of bioactive compounds and mangoes 'Kent' antioxidant activity, minimized and stored at $4{ }^{\circ} \mathrm{C}$. The alginate edible coating application together with antibrowning agents maintained the highest color values $(\mathrm{L} *$ and $\mathrm{Hue}^{\circ}$ ), increase the content of vitamin $\mathrm{C}$, total phenols and the antioxidant potential of cubes.

\subsection{Microbiological Analysis}

The pulp used, as raw material for the preparation of microcapsules passion fruit, showed no contamination by fecal coliform and total coliform and the absence of yeasts and molds was also observed.

After processing of microcapsules, the addition of sparkling mineral water and pasteurization, the analyzes of quality control was again performed to ensure the sanity of the final product. Throughout the whole storage, the bioactive water did not present contamination for microorganisms analyzed.

Oliveira (2011) studied the refrigerated storage of drops of papaya obtained by ionic gelation with alginate and packed in glass and polypropylene verified a count of yeasts and molds after 21 days of storage, $3,7 \times 10^{3} \mathrm{CFU} / \mathrm{g}$ and 5,2 $\times 10^{3}$ $\mathrm{CFU} / \mathrm{g}$ respectively.

Xavier (2014) analyzed pearls of passion fruit pasteurized obtained by ionic gelation and stored in glass packaging to \pm $5{ }^{\circ} \mathrm{C}$. The author observed that from the 28 th day of storage the samples showed contamination of Aspergillus spp and Penicillium spp.

The $\mathrm{CO}_{2}$ from the carbonated water used in this study causes bactericidal effect by reducing the $\mathrm{pH}$ of the water. This factor combined with the addition of sodium citrate, pasteurization of the product and refrigerated storage were presented as multiple barriers to the growth of microorganisms in bioactive water.

\section{Conclusions}

The pulp showed significant difference at $5 \%$ in most of the physic-chemical analysis in relation to the juice and the microcapsule. It is concluded that the dilution of the raw material and the addition of sodium citrate contributed more to the physicochemical changes than to alginate gelation.

For the microcapsules, it was possible to verify that the moisture content increased during the storage period $(\mathrm{p} \leq 0,05)$. For ash content, TSS, ascorbic acid, carotenoids and color parameter $\mathrm{L}$, occurred a decrease (at $\mathrm{p} \leq 0,05)$ with carbonated water storage at $5 \pm 1{ }^{\circ} \mathrm{C}$ in glass packaging for 35 days. Phenols, color parameters $\mathrm{a} *$ and $\mathrm{b}^{*}, \mathrm{Hue}^{\mathrm{o}}$ and $\mathrm{pH}$ remained constant $(\mathrm{p} \leq 0,05)$ the microcapsule after 35 days.

For carbonated water, there was a decrease of $\mathrm{pH}(\mathrm{p} \leq 0,05)$ and a non-significant increase for the ash content.

From the 7th day of storage, the microcapsules and the water showed equalization of the levels of ascorbic acid, total 
carotenoids and total phenols. Meaning that in the same storage time there was no significant difference among samples $(p \leq 0,05)$. This result indicates migration of the bioactive compounds of the microcapsule to water and consequently the bioactivation of carbonated mineral water.

The bioactive water stored in glass container for 35 days at $5{ }^{\circ} \mathrm{C}$ showed no contamination for the microorganisms analyzed. The $\mathrm{CO}_{2}$ from the carbonated water, associate to the addition of sodium citrate, pasteurization of the product and to the refrigerated storage were presented as multiple barriers for the growth of microorganisms in the product.

\section{Acknowledgements}

This project was supported by National Council for Scientific and Technological Development (CNPq) and by the National Council for the Improvement of Higher Education (CAPES).

\section{References}

[1] Adolfo Lutz Institute. (2005). Normas Analíticas do Instituto Adolfo Lutz: Métodos químicos e físicos para análise de alimentos. (3th ed). São Paulo: IAL.

[2] Água \& Vida. (2012). Água mineral lidera ranking de vendas no primeiro bimestre de 2011. Água \& Vida. Available in: $<\mathrm{http}: / /$ www.revistaaguaevida.com.br/?p=56>. Accessed July $15,2013$.

[3] Almeida, R. F., Martins, M. L. L., Resende, E. D., Vitorazi, L., Carlos, L. A. \& Pinto, L. K. A. (2006). Influência da temperatura de refrigeração sobre as características químicas do mamão cv. "Golden". Ciência e Tecnologia de Alimentos, $26,3,577-581$.

[4] AOAC - Association of Official Analytical Chemists. (1984). Official methods of analysis of the Association of Official Analytical Chemists. (14th ed.). Arlington: A.O.A.C.

[5] AOAC - Association of Official Analytical Chemists. (1996). Official Methods of analysis of the Association of Official Analytical Chemists. Arlington: A.O.A.C., Chapter 44.

[6] Arrazola, G., Herazo, I. \& Alvis, A. (2014). Obtención y Evaluación de la Estabilidad de Antocianinas de Berenjena (Solanum melongena L.) en Bebidas. Información Tecnológica, 25, 3, 43-52.

[7] Benassi, M. T. \& Antunes, A. J. (1988). A comparison of meta-phosphoric and oxalic acids as extractant solutions for the determination of vitamin $\mathrm{C}$ in selected vegetables. Arquivos de Biologia e Tecnologia, 31, 4, 507-513.

[8] Brasil. (2005). ANVISA - Agência Nacional de Vigilância Sanitária. Resolução de Diretoria Colegiada - RDC no 274, de 22 de setembro de 2005. Anexo: "Regulamento técnico para águas envasadas e gelo". Brasília: Diário Oficial da União.

[9] Castro, L. R. S., Carvalho, J. S. \& Vale, V. L. C. (2010). Avaliação microbiológica de diferentes marcas de água mineral. Revista Baiana de Saúde Pública, 34, 4, 835-844.
[10] Couto, A. B. B., Aguiar, I. B., Oliveira, C. S., Gomes, F. S., Freire Jr., M., Cabral, L. M. C. \& Leal Jr., W. F. (2011). Caracterização físico-química maracujá-amarelo (Passiflora edulis fo. Flavicarpa) cultivado em sistema orgânico e convencional. Embrapa Agroindústria de Alimentos - Article in Annals of Congress (ALICE).

[11] De'Nobili, M. D., Curto, L. M., Delfino, J. M., Soria, M., Fissore, E. N. \& Rojas, A. M. (2013). Performance of alginate films for retention of $\mathrm{L}-(+)$-ascorbic acid. International Journal of Pharmaceutics, 450, 1-2, 95-103.

[12] Endo, E., Bertoldi, M. C., Pinheiro, N. M. S., Arruda, A. C. \& Minim, V. P. R. (2009). Caracterização do mercado consumidor de "água aromatizada": hábitos e motivações para o consumo. Ciência e Tecnologia de Alimentos, 29, 2, 365-370.

[13] Guadarrama-Lezama, A. Y., Dorantes-Alvarez, L., JaramilloFlores, M. E., Pérez-Alonso, C, Niranjan, K. \& AlamillaBeltrán, L. (2012) Preparation and characterization of nonaqueous extracts from chilli (Capsicum annuum L.) and their microencapsulates obtained by spray-drying. Journal of Food Engineering, 112, 1-2, 29-37.

[14] IBGE - Instituto Brasileiro de Geografia e Estatística. (2010). Banco de dados agregados. Sistema IBGE de Recuperação Automática - SIDRA. Available in: <http://www.ibge.gov.br > . Accessed January 28, 2014.

[15] Jiang, T. (2013). Effect of alginate coating on physicochemical and sensory qualities of button mushrooms (Agaricus bisporus) under a high oxygen modified atmosphere. Postharvest Biology and Technology, 76, 91-97.

[16] Johnston, C. S. \& Bowling, D. L. J. (2002). Stability of ascorbic acid in commercially available orange juices. Journal of the American Dietetic Association, 102, 525-529.

[17] Lessa, A. O. (2011). Determinação do teor de compostos fitoquímicos e estudo do potencial para processamento da polpa de frutos de maracujá das espécies silvestres (Passiflora setacea DC, Passiflora cincinnata MAST). 83 p. Dissertation (Master in Food Engineering) - State University of Southwest Bahia, Itapetinga.

[18] Lichtenthaler, H. K. (1987). Chlorophylls and carotenoids: pigments of photosynthetic biomembranes. Methods of Enzymology, 148, 350-382.

[19] Lozano, M. I. C. (2010). Efecto de las condiciones de proceso en la conservación de alimentos encapsulados por el método de gelificación iónica. 127p. Dissertation (Master in Food Science) - National School of Biological Sciences, National Polytechnic Institute, Mexico.

[20] Mineral Waters of the World. (2013). Health Issues. Mineral Waters of the World. Available in: $<$ http://www.mineralwaters.org/index.php?func=f\&parval=hea lth/index $>$. Accessed July 15, 2013.

[21] Moura, L. R. C., Porto, G. D., Cunha, N. R. S., Moura, L. E. L. \& Veiga, R. T. (2011). O comportamento de compra e a percepção dos atributos da água mineral pelos consumidores. Perspectiva, 35, 130, 97-112.

[22] Mukai-Correa, R., Prata, A. S., Alvim, I. D. \& Grosso, C. (2005). Caracterização de microcápsulas contendo caseína e gordura vegetal hidrogenada obtidas por gelificação iônica. Brazilian Journal of Food Technology, 8, 1, 73-80. 
[23] Oliveira, E. M. S., Regis, S. A. \& Resende, E. D. (2011). Caracterização dos resíduos da polpa do maracujá-amarelo. Ciência Rural.

[24] Oliveira, J. E. D. \& Marchini, J. S. (1998). Ciências Nutricionais. São Paulo: Sarvier.

[25] Oliveira, M. C. (2011). Estudo do processo de obtenção de gotas de mamão (Caricapapaya L.) por esferificação básica. 87p. Dissertation (Master in Food Science and Technology) Federal University of Sergipe, São Cristóvão.

[26] Pasin, B. L., Azón, C. G. \& Garriga, A. M. (2012). Microencapsulación con alginato en alimentos. Técnicas y aplicaciones. Revista Venezolana de Ciencia y Tecnología de Alimentos, 3, 1, 130-151.

[27] Passos, M. C. L. M. S., Lima, M. A. C., Amariz, A., Ribeiro, T. P., Trindade, D. C. G. \& Antão, T. S. (2009). Utilização de revestimentos à base de alginato na conservação pós-colheita de manga "Tommy Atkins". Embrapa Agroindústria de Alimentos - Artigo em anais de congresso (ALICE), 181-187.

[28] Paulo, E. M., Assis, S. A. \& Santos, V. L. C. S. (2009). Polímeros constituídos por carboidratos utilizados no processo de microencapsulação de bactérias: uma revisão. Sitientibus Série Ciências Biológicas, 9, 4, 185-191.

[29] Qv, X., Zeng, Z. \& Jiang, J. (2011). Preparation of lutein microencapsulation by complex coacervation method and its physicochemical properties and stability. Food Hydrocolloids, $25,6,1596-1603$.

[30] Ragazzi, E. \& Veronese, G. (1973). Quantitative analysis of phenolics compounds after thin-layer chromatographic separation. Journal of Chromatography, 77, 369-375.

[31] Ramos, M. F. S. (2006). Desenvolvimento de microcápsulas contendo fração volátil de copaíba por spray-drying: estudo da estabilidade e avaliação farmacológica. 132p. Doctoral thesis (Pharmaceutical Sciences) - Faculty of Pharmaceutical Sciences, University of São Paulo, Ribeirão Preto.
[32] Rizzi, L. C., Rabello, L. A., Morozini Filho, W., Savasaki, E. T. \& Kavati, R. (1998). Cultura do maracujá-azedo. Campinas: Coordenadoria de Assistência Técnica Integral.

[33] Robles-Sánchez, R. M., Rojas-Graü, M. A., Odriozola-Serrano, I., González-Aguilar, G. \& Martin-Belloso, O. (2013). Influence of alginate-based edible coating as carrier of antibrowning agents on bioactive compounds and antioxidant activity in fresh-cut Kent mangoes. Food Science and Technology, 50, 1, 240-246.

[34] Rosa, C. G., Borges, C. D., Zambiazi, R. C., Rutz, J. K., Luz, S. R., Krumreich, F. D., Benvenutti, E. V. \& Nunes, M. R. (2014) Encapsulation of the phenolic compounds of the blackberry (Rubus fruticosus). Food Science and Technology, $58,2,527-533$

[35] Rutz, J. K. (2013). Caracterização e microencapsulação de suco de pitanga roxa (Eugenia uniflora L.). 105p. Dissertation (Master in Food Science and Technology) - Federal University of Pelotas, Pelotas.

[36] Silva, G. J. F., Constant, P. B. L., Figueiredo, R. W. \& Moura, S. M. (2010). Formulação e estabilidade de corantes de antocianinas extraídas das cascas de jabuticaba (Myrciaria ssp). Alimentos e Nutrição, 21, 3, 429-436.

[37] TACO. (2011). Tabela Brasileira de Composição de Alimentos. (4th ed.). Campinas: NEPA- UNICAMP.

[38] Vicentino, S. L., Floriano, P A., Dragunski, D. C. \& Caetano, J (2011). Filmes de amidos de mandioca modificados para recobrimento e conservação de uvas. Química Nova, 34, 8, 1309-1314.

[39] Xavier, A. C. R. (2014). Pérolas de maracujá obtidas por processo de gelificação iônica. 69p. Dissertation (Master in Food Science and Technology) - Federal University of Sergipe, São Cristóvão. 